\title{
Vasopressin mRNA Regulation in Individual Hypothalamic Nuclei: A Northern and in situ Hybridization Analysis
}

\author{
Thomas G. Sherman, ${ }^{\star}$ Jeffrey F. McKelvy, $†$ and Stanley J. Watson* \\ *Mental Health Research Institute, University of Michigan, Ann Arbor, Michigan 48109, and \\ †Department of Neurobiology and Behavior, S.U.N.Y. at Stony Brook, \\ Stony Brook, New York 11794
}

\begin{abstract}
The present study examines the relative levels of vasopressin (AVP) mRNA within the paraventricular (PVN), supraoptic (SON), and suprachiasmatic (SCN) nuclei of the rat hypothalamus, and details the rates at which these levels change over the course of a $6 \mathrm{~d}$ salt-loading regimen. The quantitation of vasopressin mRNA was achieved by using three different procedures: (1) cell-free translation in rabbit reticulocyte lysate or (2) Northern analysis of poly(A)RNAs isolated from micro-punch dissected SON, PVN, and SCN, and (3) in situ hybridization histochemistry. The former involved the quantitative immunoprecipitation of the neurophysin precursors containing arginine ${ }^{8-}$ vasopressin (AVP) or oxytocin, and the latter two techniques employed a radiolabeled synthetic oligodeoxynucleotide complementary to the $3^{\prime}$ region of the AVP mRNA. Both the cellfree studies and the Northern gel analyses detected a sevenfold increase of AVP mRNA in the SON, a fivefold increase in the PVN, and no significant change in the SCN following $6 \mathrm{~d}$ of salt-loading. After the initiation of salt-drinking, these increases were shown to occur between 24 and $48 \mathrm{hr}$ in the SON and between 48 and $72 \mathrm{hr}$ in the PVN. The in situ hybridization studies revealed the anatomically correct hybridization of either ${ }^{32} \mathrm{P}$ - or ${ }^{3} \mathrm{H}$-labeled AVP oligonucleotide to magnocellular perikarya within both the SON and PVN. Autoradiographic grains could be shown to be confined to the cytoplasm of these cells, and could be co-localized with immunoreactivity directed against the carboxy terminus of the AVP percursor. Comparison of x-ray level autoradiograms of control and 6 day salt-loaded SON revealed up to a sevenfold increase in specific signal in the saltloaded sections. It is concluded that the response of AVP mRNA to osmotic stimuli in the three hypothalamic nuclei is heterogeneous, and that this heterogeneity can be explained by separating AVP neurons into two systems: one responsible for eliciting the antidiuretic actions of AVP via plasma AVP levels, and the other involved in CNS activities not directly involved with antidiuresis.
\end{abstract}

Neurons containing arginine ${ }^{8}$-vasopressin (AVP) immunoreactivity are principally located within three cellular groups in the rat hypothalamus: the paraventricular (PVN), the supraoptic

Received Aug. 26, 1985; revised Oct. 14, 1985; accepted Oct. 23, 1985.

This work was supported in part by NIMH N.R.S.A. Grant F32 MH09239-01 and NIADDK Pilot Project Grant P30 AM34933-10 to T.G.S., NSF Grant BNS 7684506 to J.F.M., and NIMH Grant 1 F 32 MH09239-01, NIADDK Core Grant P30 AM34933-01, and a grant from the Theophile Raphael Research Fund to S.J.W. We gratefully acknowledge the expert technical assistance of Sharon Burke and Michael E. Lewis in the in situ studies. We would also like to thank Huda Akil, Joseph G. Verbalis, and Joseph A. Majzoub for their helpful discussions. Special thanks to Alan G. Robinson for the gift of his anti-RNp antisera.

Correspondence should be addressed to Thomas G. Sherman, Ph.D., Mental Health Research Institute, University of Michigan, 205 Washtenaw Place, Ann Arbor, MI 48109-0010.

Copyright (C) 1986 Society for Neuroscience $0270-6474 / 86 / 061685-10 \$ 02.00 / 0$
(SON), and the suprachiasmatic (SCN) nuclei. The PVN and SON, comprising the hypothalamo-neurohypophysial system, are two magnocellular areas that account for greater than $60-$ $70 \%$ of the hypothalamic perikaryal AVP, with the remainder scattered in accessory cell groups and non-magnocellular neurons of the SCN (Rhodes et al., 1981). Neuroendocrine axons projecting from the PVN and SON to the posterior pituitary and median eminence are the primary sources of circulating AVP (Sachs et al., 1967). In addition, axons from the SCN, and, to a smaller extent, the SON and PVN, also project to many other extrahypothalamic sites within the brain and spinal cord. Even though the precise roles for these many projections of AVP are, in most cases, unknown, it remains clear that the cardinal physiological functions of AVP are threefold (Valiquette, 1980): (1) to control the renal excretion of water; (2) to regulate hemodynamic parameters dependent on effective blood volume (vasopressor activity); and (3) to regulate the secretion of ACTH. Although evidence for these roles for AVP has been reviewed extensively elsewhere, the following regulatory aspects are germane: (1) The secretory behavior of AVP from the posterior pituitary is tightly regulated by plasma osmolarity and/or plasma $\left[\mathrm{Na}^{+}\right]$(McKinley et al., 1978; Vernay, 1947); (2) AVP can be demonstrated to interact centrally with neurogenic mechanisms of blood pressure regulation (Ferrario et al., 1985) and systemically with a good correlation of plasma AVP levels with central venous pressure, with responses to blood volume changes of both emergency (hemorrhage) and nonemergency (assuming an upright posture) magnitude (Claybaugh and Share, 1973; Moses and Miller, 1974); and (3) AVP, along with corticotropin releasing factor (CRF), can stimulate the release of $A C T H$ from the anterior pituitary via its secretion from the median cminence, a pathway also implicated in AVP responses to stress (for a review, see Makara et al., 1981). In a broad sense, these functions are subserved by three AVP efferent systems projecting, respectively, to posterior pituitary, extrahypothalamic CNS, and brain stem (Matsuguchi et al., 1982), and the external layer of the median eminence.

The contributions of the two nonposterior pituitary projection systems of AVP to the endocrine effects of circulating AVP remain essentially unknown, even though the hypothalamoneurohypophysial system itself has been studied extensively by many biological disciplines. Few studies exist that have carefully investigated the biological responses of the three hypothalamic AVP cell groups to physiological stimuli known to regulate the secretory and/or biosynthetic activity of AVP neurons (i.e., osmotic challenge, hemorrhage, stress, etc.; Burbach et al., 1984; Sherman et al., 1985; Zerbe and Palkovits, 1984).

On the other hand, many biosynthetic studies have been performed on whole hypothalamus or the SON nucleus. It has been clearly shown, for example, in a sequence of studies initiated by the novel Common Precursor proposal of Sachs and Taka- 
batake (1964), that the biogenesis of biologically active AVP proceeds via the proteolytic processing of a high-molecularweight precursor (Gainer et al., 1977a; Schmale and Richter, 1981). The biosynthesis of this precursor was shown to be greatly increased by chronic osmotic stimulation (Gainer et al., 1977b). With the molecular cloning of the mRNA for the bovine AVP precursor (Land et al., 1982), and subsequent isolation of the rat gene (Schmale et al., 1983), DNA sequence information became available for investigations into the identification and quantitation of AVP mRNA in response to physiological manipulations, using synthetic oligodeoxynucleotide probes. Such studies have shown that hypothalamic levels of AVP mRNA increase 8-10-fold following chronic salt-loading or dehydration (Majzoub et al., 1983; Sherman et al., 1985).

These later studies, utilizing quantitative Northern and dotblot analyses, provide a level of information to the regulatory neurobiologist not readily available by other techniques. Quantitative RNA studies, for example, have indicated that, under chronic secretory demand, the degrees to which protein processing and translational enzymes can be stimulated are limited, and that increases in specific mRNA pool sizes must be made in order to increase the biosynthetic capacity of a neuron. Unlike peptide levels, specific mRNA pool sizes reflect the long-term biosynthetic preparedness of a cell. Specific mRNA levels, therefore, are an additional regulatory site of peptide cell biology. This reasoning has prompted us, in this paper, to expand on previous physiological studies in the hypothalamus in order to investigate the SON, PVN and SCN nuclei, individually, to determine both the degree to which these areas of the rat hypothalamus are osmotically responsive and the rates at which AVP mRNA levels in these areas increase, thereby determining the relative contributions of individual hypothalamic nuclei to posterior pituitary function, as well as beginning to clarify the responses of the 3 AVP nuclei, portions of which project to targets throughout the CNS, to systemic hyperosmicity.

The anatomical discreteness of the SON, PVN, and SCN was maintained throughout this study by coupling two techniques: (1) Palkovits' punch microdissection with mRNA quantitation (cell-free translation and Northern analysis), which not only allows for the preparation of tissue devoid of contamination by adjacent AVP cellular groups but, when carefully performed, provides for an RNA sample greatly enriched for the nuclei of interest; and (2) in situ hybridization histochemistry, an exciting and complex set of anatomical/molecular biological techniques in the early stages of development, which is now beginning to allow meaningful questions to be asked about regulatory molecular neurobiology at the single-cell level.

\section{Materials and Methods}

\section{Salt-loading}

Male Sprague-Dawley rats (200-225 gm; Charles River, Kennsington, WI) were housed in individual cages with a $12 \mathrm{hr}$ light-dark cycle $(0600$ on, $1800 \mathrm{off}$ ). Animals were kept for 1 week prior to the start of the experiment and were given free access to water and Purina Lab Rodent Chow (Beynen, 1985). For salt-loading, rats were given $0.34 \mathrm{~m}(2 \% \mathrm{wt} /$ vol) sodium chloride ad libitum for their drinking water. Plasma $\left[\mathrm{Na}^{+}\right]$ was determined in acidified plasma by a sodium electrode (Beckman Astro-8 Analyzer).

\section{Palkovits' punch microdissection}

Cell-free translation studies. Hypothalamic nuclei were punched from $1.0 \mathrm{~mm}$ dry-ice frozen brain sections using a $1.0-\mathrm{mm}$-I.D. punch, essentially as described (Palkovits and Brownstein, 1983). Northern gel analysis studies were as described above, except dissections were carried out using rapidly chilled brain sections instead of frozen ones. Punches were kept at $-80^{\circ} \mathrm{C}$ until use.

\section{$R N A$ isolation}

Total RNA was extracted from frozen tissue after a modification of Chirgwin et al. (1979). Punched tissue from one to three animals was homogenized in $0.5 \mathrm{ml}, 6.0 \mathrm{M}$ guanidinium-isothiocyanate (Fluka Chemical Corp.) containing $25 \mathrm{~mm}$ sodium citrate, pH $7.0,17 \mathrm{~mm}$ $N$-lauroyl sarkosinc, and $0.86 \mathrm{M} 2$-mcrcaptocthanol. Homogenates were incubated at $65^{\circ} \mathrm{C}$ for $10 \mathrm{~min}$ and centrifuged for $10 \mathrm{~min}$ at $4^{\circ} \mathrm{C}$ in a Fisher $235 \mathrm{~A}$ microfuge. To each $1.0 \mathrm{ml}$ volume of supernatant, $0.4 \mathrm{gm}$ cesium chloride (CsCl) was added, and this was layered over $1.2 \mathrm{ml}$ of a $5.7 \mathrm{M} \mathrm{CsCl}, 0.1 \mathrm{~m}$ EDTA, pH 7.5, cushion in a Sarstedt polyallomer tube for the Beckman SW 50.1 Ti rotor. Gradients were centrifuged for $16 \mathrm{hr}$ at $20^{\circ} \mathrm{C}$ at $35,000 \mathrm{rpm}$. The supernant was removed by aspiration, the tube inverted, and the walls dried with a cotton-tipped applicator. The RNA pellet was resuspended in $0.2 \mathrm{ml}, 0.1 \mathrm{M}$ Tris- $\mathrm{HCl}, \mathrm{pH} 7.3$, containing $12.5 \mathrm{~mm}$ EDTA, $0.15 \mathrm{M} \mathrm{NaCl}, 0.2 \% \mathrm{wt} / \mathrm{vol}$ SDS, and 0.02 $\mathrm{mg} / \mathrm{ml}$ proteinase $\mathrm{K}$, and incubated at $37^{\circ} \mathrm{C}$ for $30 \mathrm{~min}$. The RNA was extracted once with phenol/chloroform, once with chloroform, and precipitated from ethanol.

\section{Poly $(A) R N A$ isolation}

Poly(A)RNAs were isolated using a microbatch method employing 3$4 \mathrm{mg}$ of oligo(dT)-cellulose (Type 3; Collaborative Research). Total RNAs were heat denatured at $85^{\circ} \mathrm{C}$ for $5 \mathrm{~min}$ in $100 \mu \mathrm{l}$ water. One volume of $2 \times$ high-salt buffer ( $2 \times$-HSB: $20 \mathrm{~mm}$ sodium citrate, pH 7.5, $2 \mathrm{~mm}$ EDTA, $1.0 \mathrm{~m} \mathrm{NaCl}$ ) was added. This was transferred to a tube containing 3-4 mg of oligo(dT)-cellulose pre-equilibrated in 1 $1 \times$-HSB. After vortexing gently $3-4 \times$ over a $5 \mathrm{~min}$ period at $24^{\circ} \mathrm{C}$, the resin was pelleted and the supernatant removed. The pellet was washed twice with $1 \times-\mathrm{HSB}$ and once with intermediate-salt buffer (containing $0.1 \mathrm{M} \mathrm{NaCl}$ ). The RNA was eluted in five $50 \mu \mathrm{l}$ washes of water and co-ethanol precipitated with $1.0 \mu \mathrm{g} E$. coli tRNA (cell-free translation studies) from $0.25 \mathrm{~m}$ potassium acetate, $\mathrm{pH} 5.2$, or $10 \mu \mathrm{g}$ Baker's yeast tRNA (Northern gel studies) from $0.25 \mathrm{M}$ sodium acetate, $\mathrm{pH} 5.2$.

\section{Poly(A)RNA quantitation}

The poly(A) content of samples of total RNA was determined essentially as described (Pfeifer-Ohlsson et al., 1984) using ${ }^{3} \mathrm{H}$-poly(U) (New England Nuclear).

\section{In vitro biosynthesis and immunoprecipitation of $A V P-R N p I$ and $O X Y-R N p$ II precursors}

Cell-free translations using rabbit reticulocyte lysates (Bethesda Research Labs) and immunoprecipitations using protein $A$ affinity-purified IgG against rat neurophysin (Alan G. Robinson, Pittsburgh, PA) were performed essentially as described (Sherman et al., 1984). All translations were performed in the presence of $1.0 \mathrm{~mm}$ diisopropylfuorophosphate (DFP, diisopropyl phosphofluoridate; Sigma Chemical Co.; Sherman et al., 1984) and a ${ }^{35} S$-cysteine concentration of $1.0 \mathrm{mCi} / \mathrm{ml}$ $\left(1200 \mathrm{Ci} / \mathrm{mmol}^{3 s} \mathrm{~S}\right.$-cysteine; New England Nuclear). Each sample was translated for $60 \mathrm{~min}$ at $30^{\circ} \mathrm{C}$ in a $30 \mu 1$ volume of lysate. Ribosomes and polysomal complexes were pelleted during a $15 \mathrm{~min}$ ultracentrifugation at 100,000 rpm (30 psi in an A-100 rotor) in a Beckman Airfuge. The supernatants were diluted $1: 1$ with $2 \times$ immuno-binding buffer $(2 \times$ IBB: $100 \mathrm{~mm}$ sodium phosphate, $\mathrm{pH} 8.0,0.3 \mathrm{M} \mathrm{NaCl}, 4 \% \mathrm{vol} / \mathrm{vol}$ Triton $\mathrm{X}-100,48 \mathrm{~mm}$ sodium deoxycholate, $2.0 \mathrm{~mm}$ phenylmethyl sulfonyl fluoride, $0.2 \%$ dimethyl sulfoxide, $20 \mathrm{~mm}$ cysteine, and $0.62 \mathrm{~mm}$ sodium azide). To this was added, at a final concentration of $0.5 \mathrm{mg} / \mathrm{ml}$, antirat neurophysin IgG or normal rabbit serum IgG. These were incubated at $22^{\circ} \mathrm{C}$ for $6 \mathrm{hr}$. The immunocomplexes were recovered on a $0.1 \mathrm{ml}$ volume protein $A$ Sepharose column equilibrated in $1 \times$-IBB. The resin was washed with 100 column volumes of IBB, and 50 column volumes of PBS, pH 8.0. The immunoprecipitates were collected with $1.0 \mathrm{~N}$ acetic acid and lyophilized.

Total translational activity was defined as the extent of incorporation of ${ }^{35} S$-cysteine into reduced, $S$-carboxymethylated, TCA-precipitable protein (Sherman et al., 1984).

\section{Northern analysis}

The poly(A)RNAs were resuspended in $50 \%$ deionized formamide, 20 mM morpholinepropanesulfonic acid (MOPS), pH 7.0, $5 \mathrm{~mm}$ sodium acetate, $1 \mathrm{mM}$ EDTA, and $2.2 \mathrm{M}$ formaldehyde. The RNA was denatured at $65^{\circ} \mathrm{C}$ for $10 \mathrm{~min}$ and fractionated on a $1.5 \%$ agarose gel containing 
$2.2 \mathrm{M}$ formaldehyde, $20 \mathrm{~mm}$ MOPS, $\mathrm{pH} 7.0,5 \mathrm{~mm}$ sodium acetate, and $1 \mathrm{mM}$ EDTA, using an electrophoresis buffer of the same composition without formaldehyde. The separated RNAs were passively transferred to either nitrocellulose or Nytran membranes (Schleicher \& Schuell) in $20 \times-\mathrm{SSC}(3.0 \mathrm{M} \mathrm{NaCl}, 0.5 \mathrm{M}$ sodium citrate, $\mathrm{pH} 7.2)$. Filters were prehybridized overnight at $45^{\circ} \mathrm{C}$ in a buffer containing $10 \%$ deionized formamide, $5 \times-\mathrm{SSC}, 20 \mathrm{~mm}$ sodium phosphate, $\mathrm{pH} 7.5,5 \times$ Denhardt's $\left[1 \times=0.2 \%\right.$ polyvinylpyrrolidone $\left(M_{r}=40,000\right), 0.2 \%$ Ficoll $\left(M_{r}=\right.$ $400,000$ ), and $0.2 \% \mathrm{BSA}], 0.1 \% \mathrm{SDS}$, and $10 \mu \mathrm{g} / \mathrm{ml}$ sheared, heat-denatured salmon sperm DNA. The hybridization buffer was similar except that it contained $1 \times$ Denhardt's and $1.0 \mu \mathrm{g} / \mathrm{ml}$ salmon sperm DNA.

A 26-nucleotide-long (26mer) oligodeoxynucleotide was synthesized on an Applied Biosystems Model 380A DNA synthesizer, purified, and ${ }^{32}$ P-labeled essentially as described (Lewis et al., 1985). Northern hybridizations were carried out at $45^{\circ} \mathrm{C}$ for $24-48 \mathrm{hr}$ at an oligomer concentration of 2-5 nM and a probe specific activity of approximately $10^{\circ}$ $\mathrm{dpm} / \mathrm{nmol}$. Filters were washed to a stringency of $2 \times-\mathrm{SSC}, 0.1 \% \mathrm{SDS}$, at $45^{\circ} \mathrm{C}$.

\section{In situ hybridization}

All tissue preparation, sectioning, hybridizations, and autoradiography were performed essentially as described by Lewis et al. (1985). When immunocytochemistry was performed prior to in situ hybridization, the techniques used were as described previously (Watson et al., 1982, 1983), except that all antibody-containing buffers contained $2.0 \mathrm{~mm}$ vanadyl ribonucleoside complex (VRC; Bethesda Research Labs).

Data from salt-loading experiments were compared using unpaired $t$ tests.

\section{Results}

The relative quantitation of specific $m R N A$

by cell-free translation

RNA-dependent, cell-free translation in rabbit reticulocyte lysate (RRL) is linear with respect to added RNA at only very low concentrations of RNA. With rat hypothalamic poly(A)RNA, deviations from linearity occurred at concentrations greater than $10 \mu \mathrm{g}$ RNA $/ \mathrm{ml}$, even though the observed maximum translational activity was nearly $40 \mu \mathrm{g} \mathrm{RNA} / \mathrm{ml}$ (data not shown). For the application of cell-free translation in a quantitative assay of $m R N A$ s coding for specific protcins, it was found necessary, therefore, to limit the amount of poly(A)RNA added to a $30 \mu \mathrm{l}$ translation volume to less than $0.3 \mu \mathrm{g}$. Figure 1 illustrates the linearity of prepro-AVP/RNp I translation obtained with poly(A)RNA isolated from 1 to 6 rat hypothalamic magnocellular nuclei (SON or PVN), even when this poly(A)RNA was added in conjunction with the $1.0 \mu \mathrm{g}$ of $E$. coli tRNA found necessary for quantitative recovery of the purified poly(A)RNA. The $1.0 \mu \mathrm{g}$ of $E$. coli tRNA was found to decrease total translational activity by $10-12 \%$. On average, 2 SON punches (a bilateral dissection from one rat using a 1.0-mm-I.D. punch on a 1.0 -mm-thick frozen section), weighing approximately $2-4$ $\mathrm{mg}$, wet weight, would yield 1.4-2.5 $\mu \mathrm{g}$ of total RNA, from which approximately $0.05 \mu \mathrm{g}$ of poly $(\hat{A})$-enriched RNA could be recovered. When translated in a RRL system $(30 \mu \mathrm{l})$ in the presence of $1.0 \mathrm{mCi} / \mathrm{ml}^{35} S$-cysteine $(>1200 \mathrm{Ci} / \mathrm{mmol}), 1.0 \mathrm{~mm}$ DFP, and $1.0 \mu \mathrm{g} E$. coli tRNA, $2200 \mathrm{dpm}$ could be incorporated into immunoprecipitable neurophysin precursor products, approximately $55 \%$ of which migrated as an 18,000 Da band corresponding to prepro-AVP/RNp I (Schmale and Richter, 1981; Sherman and McKelvy, 1983). The greatly homologous OXY' RNp II precursor migrated at 16,500 daltons. Because there are 36 cysteine residues divided between these 2 precursors (Ivell and Richter, 1984), the radioactivity associated with neurophysin-like immunoreactivity accounted for greater than $30 \%$ of the ${ }^{35} S$-cysteine incorporated into punched-hypothalamic poly(A)RNA-dependent, reduced, carboxymethylated, TCAprecipitable translation products. When the total translation products were examined with two-dimensional gel electropho-

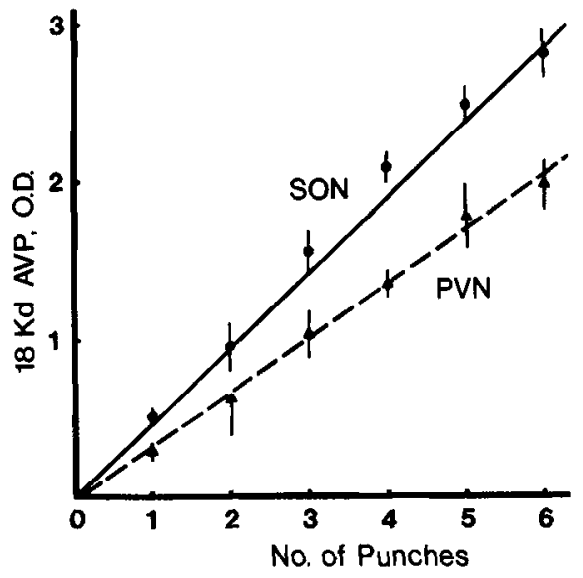

Figure 1. Linearity of punch translations. Supraoptic (SON) or paraventricular $(P V N)$ nuclei in normal Sprague-Dawley rats were punchdissected from $1.0 \mathrm{~mm}$ frozen sections using a $1.0-\mathrm{mm}-\mathrm{I}$.D. punch. Punches totaling 1, 2, 3, 4, 5, and 6 nuclei were pooled. Total RNA and poly $(A) R N A s$ were isolated and translated in vitro, and rat neurophysin immunoprecipitates collected, as described in Materials and Methods. Eluted proteins were fractionated on a $15 \%$ SDS-polyacrylamide gel. Gels werc prepared for fluorography using EN ${ }^{3} \mathrm{HANCE}$ (New England Nuclear), and exposed for 10-12 d. Densitometry on the 18,000 Da prepro-AVP/RNp I band is expressed as $0.1 \times$ total optical density (O.D.; area in pixels $\times$ average absorbance) of that band (see legend to Fig. 6). Correlation coefficients, $S O N=0.987 ; P V N=0.968$.

resis, the relative amounts of both high molecular weight forms of neurophysin were increased relative to total protein, but were by no means the only induced proteins (data not shown). Greater than $10 \%$ of the visualized proteins were induced to a recognizable degree (Sherman et al., 1984).

This assay for translatable vasopressin mRNA was applied to RNAs isolated from bilaterally-punched hypothalamic nuclei dissected from rats which had been salt-loaded for up to 6 days. The ability of SON RNA to direct the translation of preproAVP/RNp I and prepro-OXY/RNp II increased sevenfold over the course of 6 days (Fig. 2). The salt induced stimulation observed in the PVN was less pronounced, amounting to 4.3-fold. Within the sensitivity limits of this assay, no significant change was detected in the levels of non-magnocellular vasopressin mRNA in the SCN. These results are summarized in Figure 3. The ratio of translatable AVP mRNA in rat hypothalamic nuclei (SON:PVN:SCN) changes from 12:7:5 in controls to 92:38:5 in 6-day salt-loaded animals. There was no significant change in the ratio of AVP:OXY precursors using this paradigm.

Salt-loading rats with $2 \%$ saline as drinking water is well established as a powerful, albeit nonselective, chronic secretagogue for neurohypophyseal AVP. Rats quickly habituate to the salinity, effectively increasing their plasma sodium levels from $141.7 \mathrm{mEq} /$ liter to $150.7 \mathrm{mEq} / \mathrm{liter}$ after $24 \mathrm{hr}$ (Table 1). Profound body weight loss is elicited in these animals, however (Table 1). Although no plasma AVP radioimmunoassay data are presented here, this plasma $\left[\mathrm{Na}^{+}\right]$is commensurate with greater than 10-fold increases in plasma AVP(Moses and Miller, 1971).

\section{The relative quantitation of $A V P M R N A$ by Northern analysis}

A 26-nucleotide-long oligodeoxynucleotide complementary to rat vasopressin was chemically synthesized (Fig. 4) using sequence information derived from the published rat prepro-AVP/ RNp I gene structure (Schmale et al., 1983). The oligonucleotide corresponds to a 9 amino acid stretch contained within the 


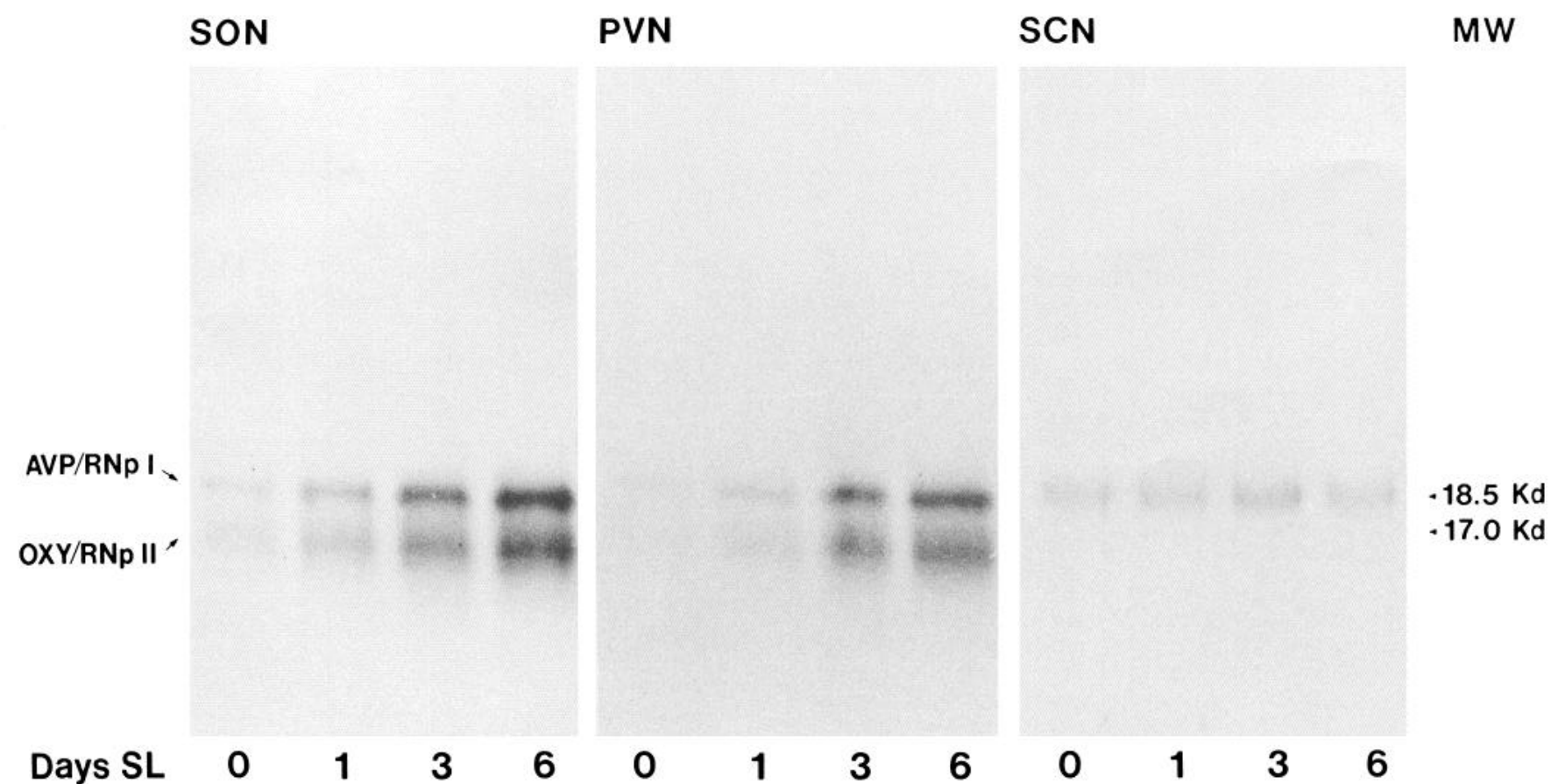

Figure 2. Translation of prepro-AVP/RNp I and prepro-OXY/RNp II in hypothalamic nuclei during salt-loading. Bilateral punches of either $S O N, P V N$, or $S C N$ were collected from $1.0 \mathrm{~mm}$ frozen sections. Poly(A)RNA was isolated from punches from individual animals, translated in vitro, and neurophysin-like immunoprecipitates collected, as described in the legend to Figure 1. Immunoprecipitates were fractionated on $15 \%$ SDS-polyacrylamide gels and prepared for fluorography. The SON and PVN gels were exposed for $12 \mathrm{~d}$, the SCN gel for $16 \mathrm{~d}$. Each point represents the bilateral nuclei from one animal.

amino-terminal half of the carboxy terminal glycoprotein moiety of the AVP precursor. Since this portion of the precursor is absent in the otherwise greatly homologous oxytocin precursor (Ivell and Richter, 1984; Land et al., 1983), no cross hybridization with oxytocin mRNA is possible. The oligonucleotide contains 77\% G:C residues and exhibits an experimentally determined $T_{\mathrm{m}}$ of $65^{\circ} \mathrm{C}$ in $2 \times-\mathrm{SSC}$ (data not shown).

Because of the greater number of animals involved in these studies, the hypothalamic nuclei dissection was altered to decrease dissection time. The sectioning and punching of fresh, chilled tissue resulted in tissue pieces approximately twice the size obtained with frozen section punches. Table 2 summarizes the yields of total RNA from SON, PVN, and SCN punches in experiments involving 3 groups of 3 animals. To normalize for the amount of poly(A)RNA isolated from these preparations, which were too small for practical quantitation by UV absorbance at $260 \mathrm{~nm}$, total poly(A) content was determined on a $10 \%$ aliquot by a solution phase ${ }^{3} \mathrm{H}$-poly $(\mathrm{U})$ hybridization assay (Table 2). The two magnocellular nuclei (SON and PVN) demonstrated a trend towards greater recovery of total RNA with salt-loading which was not statistically significant; paradoxically, these RNAs reproducibly contained a greater poly(A) content with salt-loading which, when expressed per microgram of total RNA, was decreased compared to controls (Table 2). While
Figure 3. The relative expression of AVP mRNA in hypothalamic nuclei during salt-loading, as determined by a cell-free translation assay. The 18,000 Da prepro-AVP/RNp I bands in Figure 2 were quantitated by digital densitometry on a Loats autoradiography system. The data are expressed as $0.1 \times$ total optical density (see Fig. 6). $S L 0-S L 6$ denote days salt-loaded, from 0 to $6 .{ }^{*} p \leq 0.025 ;{ }^{* *} p \leq 0.005$.

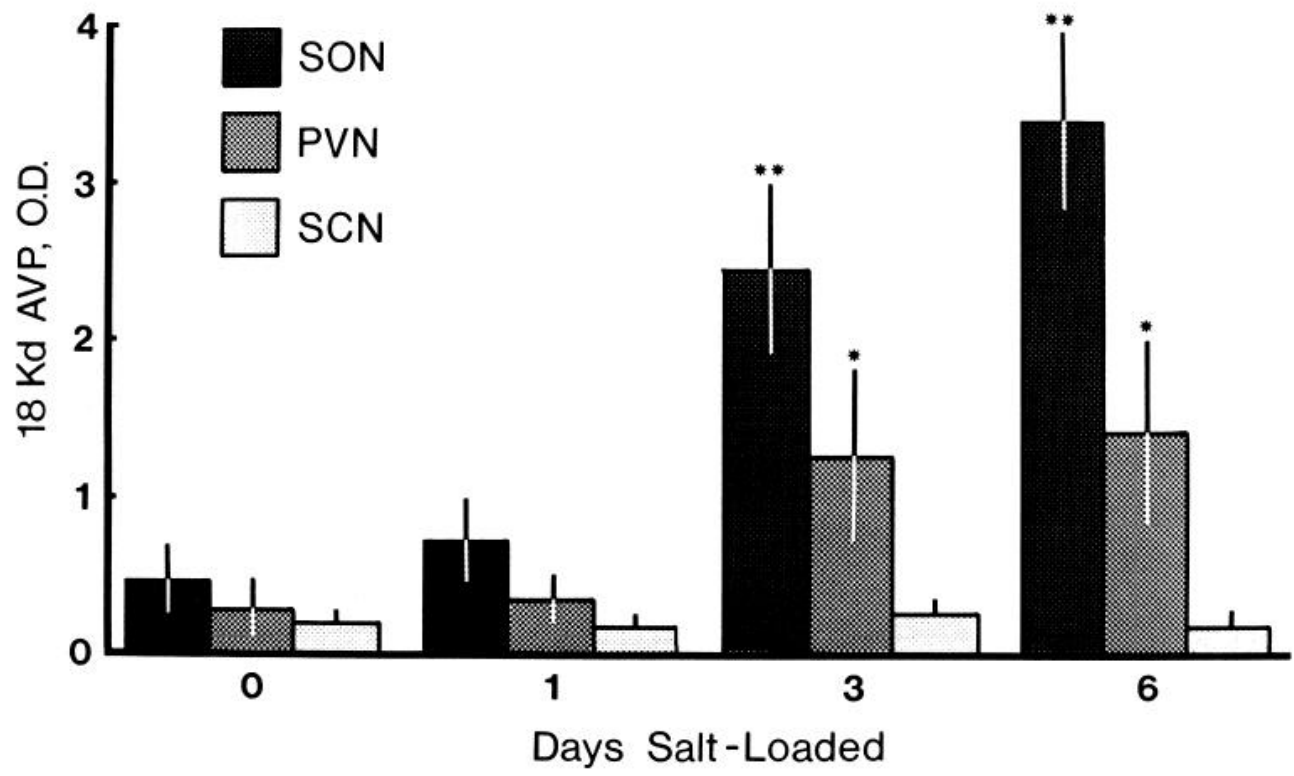




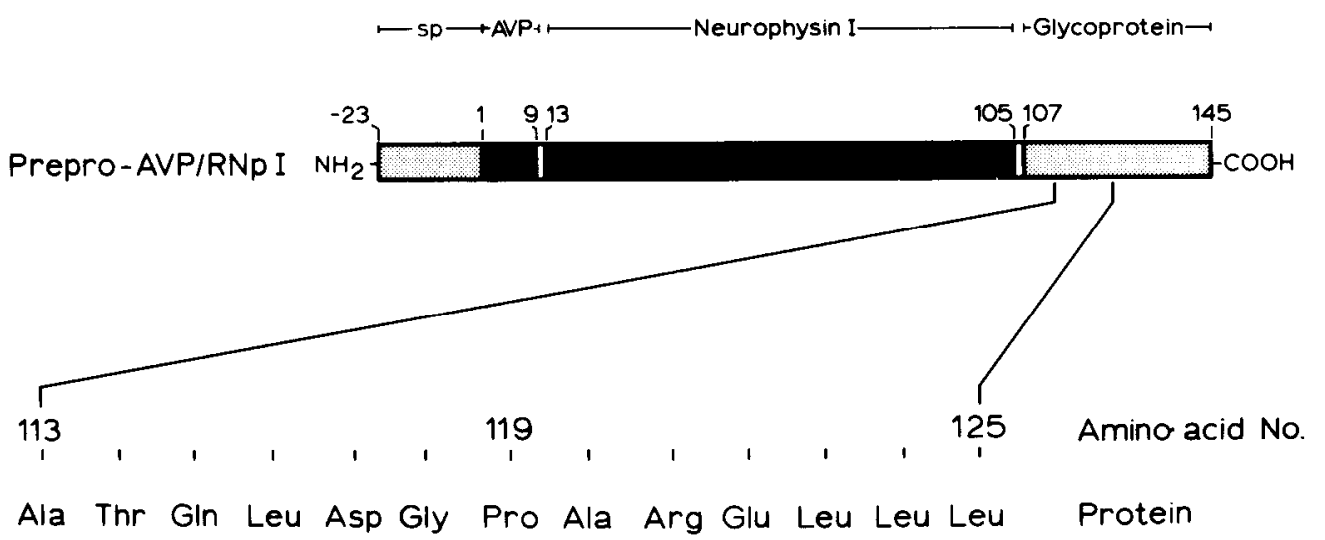

GCC ACG CAG CUG GAC GGG CCA GCC CGG GAG CUG CUG CUU

3 ' mRNA

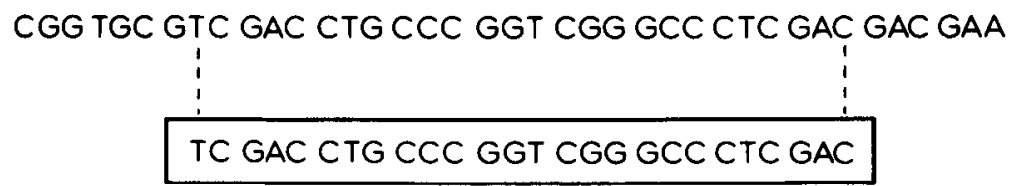

5' CDNA

5' Oligomer
Figure 4. Sequence, orientation, and region of complementarity for synthetic AVP oligonucleotide. The AVP precursor structure and RNA sequence was derived from Schmale et al. (1983). The amino acids encoded by the probe sequence are immediately adjacent to the sole glycosylation site on the AVP precursor (AA 112-114). this phenomenon is still under investigation, one probable explanation is that, as part of the overall stimulation of protein biosynthesis occurring in these nuclei due to hyperosmotic challenge, even though poly(A)RNA levels are elevated, ribosomal RNA levels are elevated even further to accommodate the greater translational activity.

Hybridization of the ${ }^{32} \mathrm{P}$-kinased oligomer to a nitrocellulose membrane containing fractionated poly(A)RNAs isolated from either SON, PVN, or SCN throughout a $6 \mathrm{~d}$ salt-loading study revealed a single band (Fig. 5) migrating at 740 nucleotides (Schmale et al., 1983). In RNAs isolated from the SON, the intensity of the AVP mRNA band incrcascd 7.3-fold over $6 \mathrm{~d}$. Vasopressin mRNA increased 5.1-fold over the same period in the PVN, and by approximately $60 \%$ in the SCN. These results, normalized for poly(A) content, are summarized in Figure 6.

As was shown in Figure 3, these data depict the increase of AVP mRNA in the magnocellular hypothalamus in response to hyperosmotic stimuli. Furthermore, in the SON, a 24-48 hr delay in this response was observed, whereas, in the PVN, this lag was between 48 and $72 \mathrm{hr}$. Each, however, plateaued on approximately the fourth day.
The relative anatomical quantitation of $A V P$ $m R N A$ by in situ hybridization

The magnocellular neurons of the rat hypothalamus lend themselves well to the technique of in situ hybridization histochemistry by virtue of their large, closely packed perikarya and their posscssion of relatively abundant pcptide hormonc mRNAs. While strategies and technical controls for this technique are adequately discussed elsewhere (Lewis et al., 1985), we present evidence here for the applicability of this procedure to the visualization and relative quantitation of specific mRNA changes in brain.

Within the SON and PVN, AVP immunoreactivity has been clearly shown to reside in large-diameter neurons $(25-35 \mu \mathrm{m})$ with characteristic distributions (Dierickx, 1980; Rhodes et al., 1981; Swaab et al., 1975). Figure 7 demonstrates that these same anatomical distributions for AVP perikarya can be reproduced autoradiographically following in situ hybridization with a radiolabeled AVP oligonucleotide. Figure $7 C$ illustrates the distribution of magnocellular AVP neurons in the PVN, using a 5 '-32P-kinased oligomer identical to that used in Figure 5 for

\begin{tabular}{|c|c|c|c|c|c|c|}
\hline Group & $\begin{array}{l}\text { Weight } \\
\text { (\% starting wt) }\end{array}$ & $n$ & $\begin{array}{l}\text { Total intake } \\
\text { (ml, 2\% saline) }\end{array}$ & $n$ & $\begin{array}{l}\text { Plasma }\left[\mathrm{Na}^{+}\right] \\
\text {(mEq/liter) }\end{array}$ & $n$ \\
\hline SLO & $100.00+7.87$ & 48 & $0.0+0.0$ & 9 & $141.7+2.7$ & 3 \\
\hline SLI & $92.76+7.75$ & 45 & $43.0+8.7$ & 9 & $150.7+1.7$ & 3 \\
\hline SL2 & $86.94+5.35$ & 42 & $113.0+23.6$ & 9 & $152.3+2.4$ & 3 \\
\hline SL3 & $84.85+6.47$ & 39 & $201.7+27.3$ & 9 & $155.7+2.8$ & 3 \\
\hline SL4 & $82.94+7.72$ & 36 & $312.3+37.4$ & 9 & $155.0+2.1$ & 3 \\
\hline SL5 & $80.30+8.11$ & 33 & $460.7+47.2$ & 9 & $155.5+2.4$ & 3 \\
\hline SL6 & $78.10+8.14$ & 30 & $627.3+52.5$ & 9 & $154.1+3.3$ & 3 \\
\hline
\end{tabular}

Male Sprague-Dawley rats, 200-225 gm, were individually housed for 1 week prior to salt-loading. Rats were provided with $200 \mathrm{ml}$ of fresh $2 \% \mathrm{NaCl}$ each day at 1000 hours, at which time body weights were recorded. Salt-loading was timed such that all animals were killed on the same day. Plasma sodium concentrations were determined as described in Materials and Methods. SLO-SL6 denote days salt-loaded, from 0 to 6. 


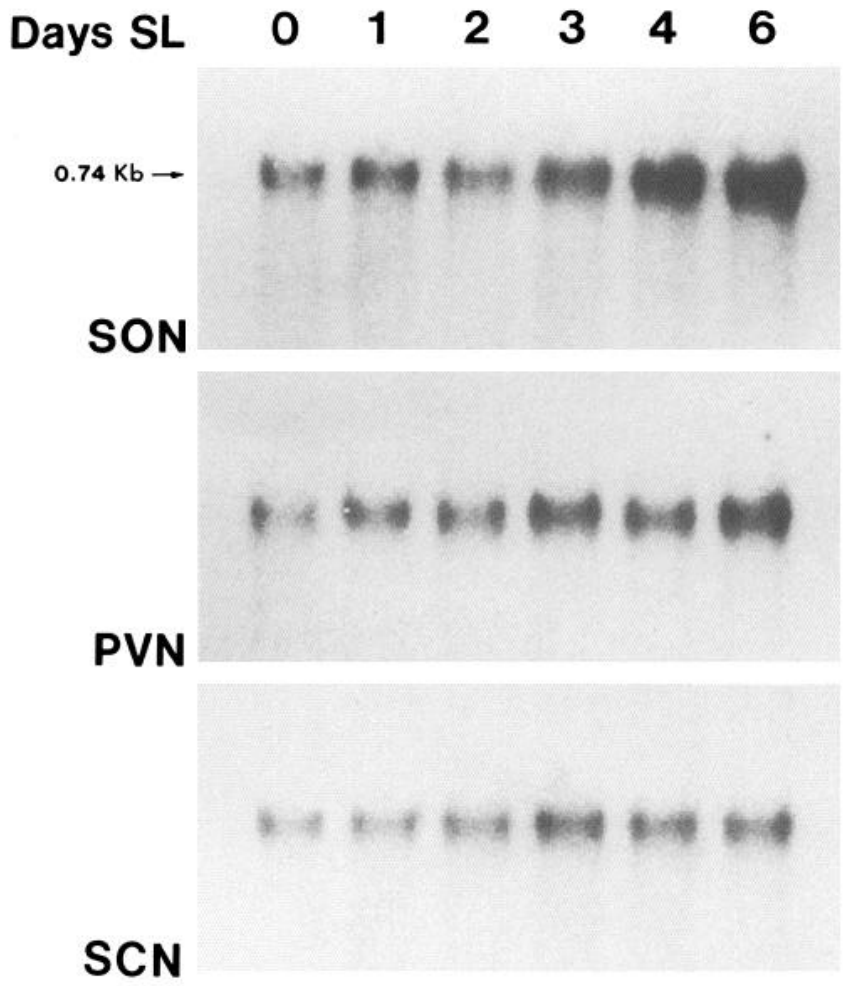

Figure 5. Northern gel analysis of AVP mRNA in hypothalamic nuclei during salt-loading. Poly(A)RNAs isolated from bilaterally punch-dissected $S O N, P V N$, and $S C N$ from 3 animals were fractionated on $1.5 \%$ formaldehyde-agarose gels and passively transferred to Nytran membranes, as described in Materials and Methods. On average, poly(A)RNA, isolated from $90 \%$ of the amount of RNA depicted in Table 1 for each nuclei, is loaded per lane. Hybridization with ${ }^{32} \mathrm{P}$-kinased AVP oligonucleotide and stringency of washes are as described in Materials and Methods. The air-dried, washed Northerns were exposed at $22^{\circ} \mathrm{C}$ for 85 $\mathrm{hr}$ for SON and PVN, and $120 \mathrm{hr}$ for SCN.

Northern analysis. Even with the pronounced autoradiographic scatter obtained with ${ }^{32} \mathrm{P}$-labeled probes due to the high-energy beta emission, the characteristic clustering of hybrid-positive neurons was recognizable. Individual cells could be visualized in the medial PVN along the third ventricle wall, where the perimeter clustering of grains suggested cytoplasmic localization of AVP mRNAs.

When the AVP oligomer was 3 '-labeled with ${ }^{3} \mathrm{H}$ using terminal deoxynucleotidyl transferase (Lewis et al., 1985), the positive identification of individual perikarya was greatly improved. Figure $7 A$ shows AVP-positive hybridization in the medial SON just lateral to the optic tract (OT). In many neurons, the grain localizations were distinctly cytoplasmic and were confined exclusively to the cell body, with no evidence for either axonal or dendritic localization. Beyond the demonstration of anatomically correct hybridization, other controls for the oligomer's AVP mRNA specificity included its exhibition of a sharp melting curve for homogeneous hybridization $\left(T_{\mathrm{m}}=65^{\circ} \mathrm{C}\right)$ and the co-localization of autoradiographic grains with AVP peptide immunocytochemistry. Figure $7 B$ illustrates this latter control with a high-magnification view of a magnocellular neuron in the rat nucleus circularis. The $10 \mu \mathrm{m}$ hypothalamic section at the level of the medial SON was first immunostained with antisera directed against the carboxy-terminal glycoprotein proportion of the AVP/RNp I precursor (CPP; Watson et al., 1982) with PAP detection, followed with in situ hybridization with the ${ }^{3} \mathrm{H}$-labeled oligonucleotide complementary to this region of the gene. The strictly cytoplasmic section through this neuron shown in Figure $7 B$ clearly displays a relatively homogeneous distribution of CPP-positive immunoreactivity punctated with autoradiographic grains.

Figure $7 D$ demonstrates that analyses such as those discussed above can be employed in the relative quantitation of specific mRNA changes in discrete hypothalamic nuclei. Serial $10 \mu \mathrm{m}$ sections through the medial SON from either control or $6 \mathrm{~d}$ salt-loaded rats were subjected, in parallel, to in situ hybridization with a ${ }^{32} \mathrm{P}$-labeled AVP oligomer. Figures $7 D_{1}$ and $7 D_{2}$ clearly demonstrate the increased labeling of the SON at the $\mathrm{x}$-ray film level, following chronic osmotic challenge. Comparative densitometry of these nuclei has yielded several-fold increases, with salt-loading ranging from 3.5- to 7.1-fold in the SON, and from 2.0- to 6.1-fold in the PVN, depending on the study and/or the section. There still exist many variables in these studies, such as possible sampling artifacts and intranucleus heterogeneity, which have yet to be accounted for. We recognize the many problems associated with studies such as these, yet we also recognize that many of the original, and seemingly insurmountable, problems are now being adequately addressed. These points will be considered in the following section.

\section{Discussion}

Three distinct, yet complementary, quantitative assessments of AVP mRNA levels clearly indicate, in the present results, that AVP cell groups within the hypothalamus respond to chronic osmotic stimulation by increasing their levels of AVP mRNA. Using a cell-free translation assay, the levels of translatable AVP and OXY mRNAs within the hypothalamus were increased significantly over the course of a $6 \mathrm{~d}$ salt-loading study. The total hypothalamic increase in AVP mRNA could be accounted for by increases in 2 of the 3 AVP cell groups in this brain region: a 7.4 -fold increase in the SON and a 4.9 -fold increase

\begin{tabular}{|c|c|c|c|c|c|c|}
\hline Group & $\begin{array}{l}\text { Total SON } \\
\text { RNA } / 3 \\
\text { rats }(\mu \mathrm{g})\end{array}$ & $\begin{array}{l}\text { Poly(A) } \\
\text { (ng) } / \mu \mathrm{g} \\
\text { SON RNA }\end{array}$ & $\begin{array}{l}\text { Total PVN } \\
\text { RNA } / 3 \\
\text { rats }(\mu \mathrm{g})\end{array}$ & $\begin{array}{l}\text { Poly(A) } \\
\text { (ng)/ } / \mu \mathrm{g} \\
\text { PVN RNA }\end{array}$ & $\begin{array}{l}\text { Total SCN } \\
\text { RNA } / 3 \\
\text { rats }(\mu \mathrm{g})\end{array}$ & $\begin{array}{l}\text { Poly(A) } \\
\text { (ng) } / \mu \mathrm{g} \\
\text { SCN RNA }\end{array}$ \\
\hline SLO & $12.6+3.1$ & $2.01+0.08$ & $12.4+2.7$ & $1.69+0.14$ & $18.1+1.3$ & $1.71+0.26$ \\
\hline SL1 & $13.7+2.4$ & $1.99+0.09$ & $11.9+2.4$ & $1.53+0.03$ & $23.9+2.2$ & $1.59+0.12$ \\
\hline SL2 & $15.1+3.0$ & $1.90+0.08$ & $12.9+3.4$ & $1.52+0.05$ & $17.2+2.8$ & $1.60+0.11$ \\
\hline SL3 & $15.6+2.9$ & $1.88+0.08$ & $13.4+2.1$ & $1.48+0.07^{*}$ & $20.2+4.1$ & $1.71+0.09$ \\
\hline SL4 & $17.2+1.5$ & $1.85+0.09 *$ & $13.8+3.1$ & $1.48+0.01^{*}$ & $19.3+2.1$ & $1.76+0.11$ \\
\hline SL6 & $17.4+2.3$ & $1.80+0.08^{*}$ & $14.2+2.5$ & $1.46+0.07^{*}$ & $16.7+3.0$ & $1.82+0.06$ \\
\hline
\end{tabular}

Each point of total RNA yield represents the average of 3 groups of 3 animals. Poly(A) content measurements were done in triplicate for each group. Ten percent of the total RNA sample from each group was used for poly(A) content assays; that $10 \%$ was divided into thirds for triplicate hybridizations against $12.61 \mathrm{ng}$ poly(U) $(249,750$ dpm). Procedures are as described in Materials and Methods. SLO-SL6 denote days salt-loaded, from 0 to 6.

$* p \leq 0.05$. 


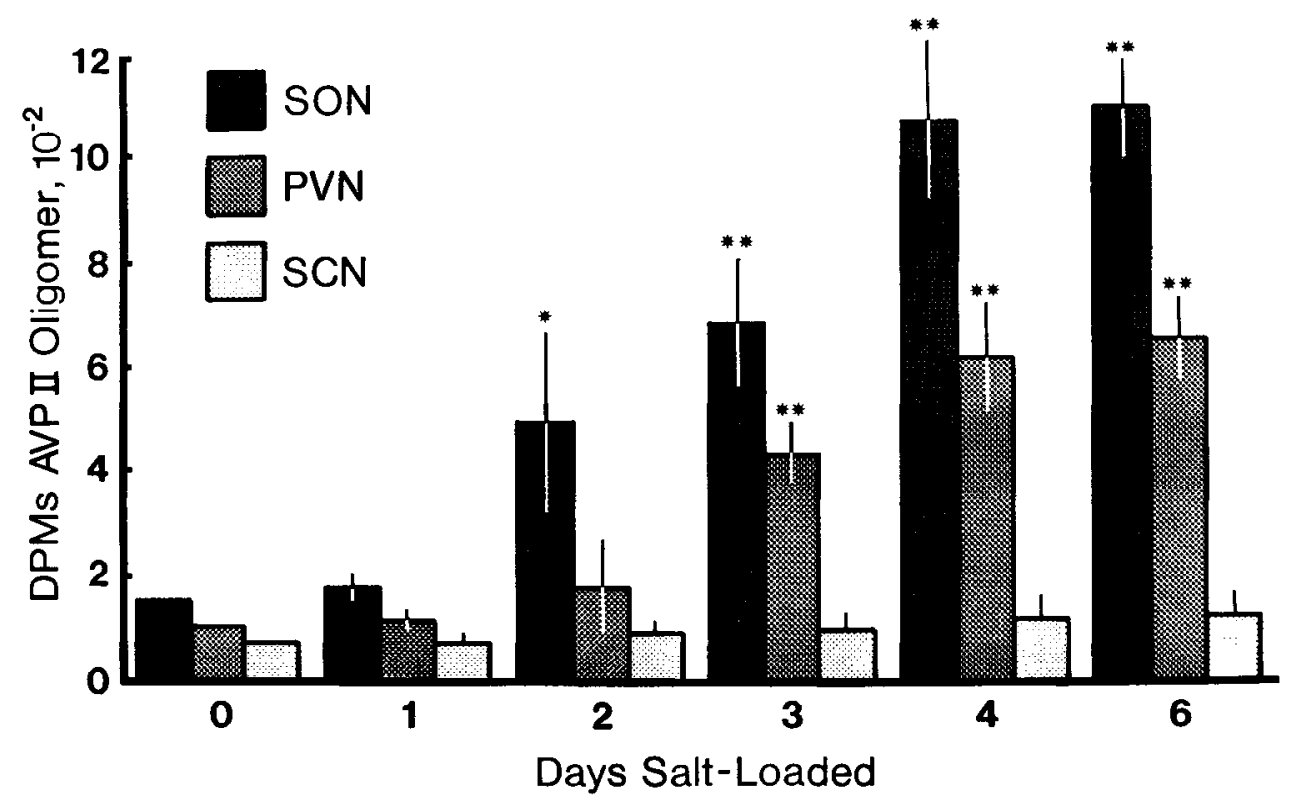

Figure 6. Quantitation of AVP mRNA in hypothalamic nuclei during salt-loading, using Northern gel analysis. The data are normalized for average poly(A) content in the SLO groups, as shown in Table 2. Hybridization-positive bands on Northern filters corresponding to AVP mRNA were quantitated using digital densitometry on a Loats autoradiography system. Total optical density was converted to dpm of ${ }^{32} \mathrm{P}$ using a standard curve constructed by the dot-blot application of ${ }^{32} \mathrm{P}$-labeled AVP oligomer to nitrocellulose. Triplicates of dot-blotted samples were either counted in a toluene-based scintillation fluid in a Beckman beta-counter or exposed simultaneously with Northern gels. Analysis revealed a film linearity of exposure (correlation coefficient $=0.993)$ up to an average absorbance of $0.83 \pm 0.02$, or $209 \pm 10 \mathrm{dpm} / \mathrm{mm}^{2}$ at $15 \mathrm{hr}$ of exposure $\left(22^{\circ} \mathrm{C}\right.$ ). For the Northern gel analyses, 100 units of optical density (area in pixels $\times$ average optical density) equaled $180.2 \pm 13.8 \mathrm{dpm}$ for the $85 \mathrm{hr}$ exposure at $22^{\circ} \mathrm{C}$. $S L 0-S L 6$ denote days salt-loaded, from 0 to $6 .{ }^{*} p \leq 0.025 ;{ }^{* *} p \leq 0.005$.

in the PVN. The only non-magnocellular cell group of the three, the SCN, displayed no significant change over the $6 \mathrm{~d}$ saltloading period, although the amounts of immunoprecipitable AVP or OXY precursor within this nuclei were sufficiently small that truly accurate estimates were difficult to obtain. The use in these immunoprecipitation experiments of an anti-rat neurophysin IgG with high affinity for both AVP and OXY precursors gave the added information, shown in Figure 2, that the translational capacity for both of these precursors was increased in poly(A)RNAs isolated from salt-loaded PVN and SON. This result is substantiated by earlier secretory and biosynthetic studies that indicated that salt-loading, as a neurohypophyseal stimulus, is equally effective for both AVP and OXY peptide secretion (Gainer et al., 1977b; Seif et al., 1977) and for stimulation of AVP and OXY's respective mRNAs (Majzoub, 1985; Majzoub et al., 1983).

Similar results were determined by Northern gel analysis. The hybridization of a 26-nucleotide-long radiolabeled AVP oligomer to a 0.74 kilobase RNA was greatly increased by salt-loading. The calculated increases in the SON and PVN, 7.1-fold and 5.3-fold, respectively, are similar in magnitude to those of the translation assays, indicating that the percentage of total AVP RNA that is translatable remains relatively constant with saltloading. Studies are currently in progress to determine what percentage this actually represents.

In sum, thus far, it is clearly established that chronic administration of a secretory stimulus results in the eventual increase in secretory product mRNAs. The differential responses of the SON, PVN, and SCN to a single stimulus, salt-loading, and the magnitudes of these responses can be partially predicted by anatomical and physiological data on the distribution and functions of AVP. As was stated in the introduction, the three main physiological functions of AVP, simply stated, are its antidiuretic, vasopressor, and CRF-like activities. The regulation of AVP secretion is complex and multipolar, with the principal regulatory stimuli appearing to be plasma osmolarity, blood volume, and some types of stress, as detected via osmoreceptors, sodium receptors, atrial stretch receptors, arterial baroreceptors, and glucocorticoid-related mechanisms (Travis and Share, 1971). Ultimately, however, some portions of this information are funneled to hypothalamic AVP neurons, whose cell bodies within the SON, PVN, and SCN possess many projections, including: (1) a massive (and perhaps, sole) neuroendocrine projection from the SON to the posterior pituitary (Rasmussen, 1940; Swanson and Sawchenko, 1983); (2) a major projection to the posterior pituitary from the PVN (Swanson and Kuypers, 1980); (3) projections from the periventricular, medial (dorsal half), and anterior parts of the PVN to the external layer of the median eminence (Dierickx et al., 1976); (4) a projection to the nucleus tractus solitarius (NTS) from a caudal division of the PVN (Swanson and Kuypcrs, 1980); and (5) projections from the SCN to the lateral habenular nucleus, the periventricular nucleus, and the organum vasculosum of the lamina terminalis (Buijs, 1978).

The main question germane to the studies presented here remains, however: Do those projections other than to the posterior pituitary contribute to the neuroendocrine effects of AVP during osmotic challenge? Do subsets of AVP neurons in each area respond differently to osmotic stimulation? If, in fact, AVP projections to regions other than the neural lobe do not respond to salt-loading, then this may partially explain the lessened response of PVN AVP mRNA compared to that of SON. Several reports have begun to address this question by using anatomically discrete biochemical assays, either to assess AVP level changes in the hypothalamus and selected terminal fields following osmotic challenge (Negro-Vilar and Samson, 1982; Zerbe and Palkovits, 1984), or to determine the relative changes in AVP mRNA in hypothalamic nuclei after chronic salt-loading (Burbach et al., 1984; Sherman et al., 1985). Radioimmunoassay data of AVP in terminal fields of the PVN and SCN (Zerbe and Palkovits, 1984) have demonstrated that some AVP neurons respond to salt-loading, as evidenced by either decreased (posterior pituitary and NTS) or increased (median eminence, 

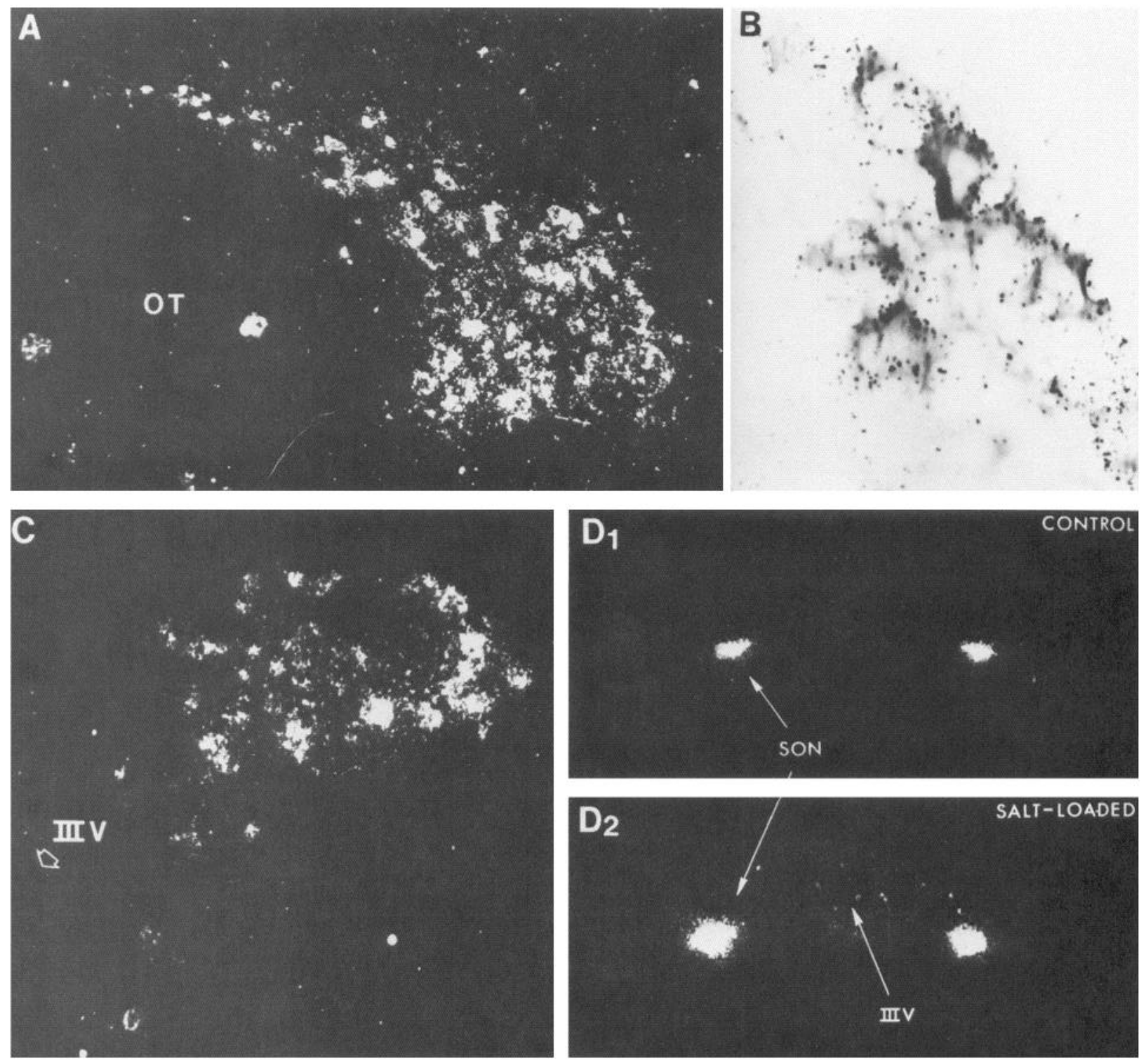

Figure 7. In situ hybridization histochemistry of SON and PVN using ${ }^{32} \mathrm{P}-$ and ${ }^{3} \mathrm{H}$-labeled AVP oligonucleotides. All sections shown here were $10 \mu \mathrm{m}$ formaldehyde-fixed. General in situ hybridization procedures were as described in Materials and Methods. $A$, Dark-field photomicrograph of a section through the medial SON of a normal rat hybridized with a $3^{\prime}-{ }^{3} \mathrm{H}$-labeled AVP oligonucleotide. Hybridization was conducted at $37^{\circ} \mathrm{C}$ with $100,000 \mathrm{dpm}$ of oligomer. The stringency of wash was $45^{\circ} \mathrm{C}$ at $0.5 \times-\mathrm{SSC}$. The section was dipped in Kodak NTB2 emulsion $\left(42^{\circ} \mathrm{C}\right.$, diluted $1: 1$ with $1.0 \mathrm{mg} / \mathrm{ml}$ sonicated Dreft), and exposed for 11 weeks at $4^{\circ} \mathrm{C}$ in the presence of Drierite desiccant. Slides were developed in Kodak D-19 for $2 \mathrm{~min}$ at $16^{\circ} \mathrm{C}$. $O T$, Optic tract. $B$, Light-field photomicrograph of the co-localization of AVP/CPP immunoreactivity with ${ }^{3} \mathrm{H}$ autoradiographic grains from AVP oligomer hybridization in the nucleus circularis. Prior to in situ hybridization, the section was immunostained for the presence of the carboxy-terminal peptide of the AVP/RNp I precursor (CPP), as described in Materials and Methods. All hybridization conditions as in $A$. $C$, Dark-field photomicrograph of a section through the mediocaudal PVN of a $6 \mathrm{~d}$ salt-loaded rat hybridized with a 5'-32P-labeled AVP oligomer. Hybridization was conducted at $45^{\circ} \mathrm{C}$ with $500,000 \mathrm{dpm}$ of probe. The stringency of wash was $45^{\circ} \mathrm{C}$ at $0.5 \times-\mathrm{SSC}$. Autoradiography, as described in $A$. Ten day exposure. IIIV. Third ventricle. $D_{1}$ and $D_{2}$, Dark-field print of in situ hybridization in control versus $6 \mathrm{~d}$ salt-loaded SON with a ${ }^{32} \mathrm{P}$-labeled AVP oligomer. Hybridizations and wash stringency, as described in $C$. Air-dried sections were exposed for $45 \mathrm{hr}$ against Kodak XAR-5 $\mathrm{x}$-ray film at $22^{\circ} \mathrm{C}$. Panels shown are representative segments of 6 serial sections through the medial SON from control or salt-loaded animals. $I I I V$, Third ventricle.

subfornical organ, and amygdala) AVP levels. Although the AVP peptide changes, other than those in the posterior pituitary, were modest, it remains difficult to infer from these data whether or not this degree of neuronal responsiveness is sufficient to induce AVP mRNAs, and, therefore, contribute to an overall induction in AVP message in the PVN. The PVN projection to the NTS, for example, is a good case in point. Depletion of AVP from terminals in the NTS with salt-loading suggests a positive response of these neurons to osmolarity (Zerbe and Palkovits,
1984), perhaps as part of a plasma osmolarity/cardiovascular function relationship (Ferrario et al, 1985; Matsuguchi et al., 1982). It can be argued, however, that the amounts of peptide hormone required to convey information in synaptic secretory activity, such as seen here, are much smaller than that required for neuroendocrine secretory activity; consequently, the cell's biosynthetic capacity is not exceeded, no increases in mRNA pools are required, and no contribution to osmotically induced PVN AVP mRNA would be observed. Although this argument 
is speculative, the evidence presented here suggests that the magnitude of AVP mRNA increases in the SON, PVN, and SCN is correlated with the extent to which each of these nuclei projects to the neural lobe. The biosynthetic requirements for neuroendocrine (hormonal) secretion, therefore, may rely more heavily on inducible mRNA pools. Clearly, however, the roles for PVN AVP are multifaceted, and this, perhaps, is reflected in this nuclei's muted response to a single stimulus (salt-loading).

The introduction of in situ hybridization histochemistry may permit the type of sub-nuclear or cellular analyses necessary to properly examine the probable heterogenic responsiveness of the PVN (Swanson and Sawchenko, 1983; Wolfson et al., 1985). The use of ${ }^{3} \mathrm{H}$-labeled oligomers, as was shown in Figure $7 A$, allows visualization of cytoplasmic mRNA within single magnocellular neurons. Examination of nuclear heterogeneity, such as that seen in the PVN, by in situ hybridization, should resolve those questions not answerable by even the best dissections. A recent report, for example, has confirmed the immunocytochemical evidence for AVP expression within CRF cells of the parvocellular PVN following adrenalectomy (Sawchenko et al., 1984), by using in situ hybridization with AVP oligonucleotides (Wolfson et al., 1985). At a more quantitative level, we are confident that whole-nuclear averaging quantitations, such as those shown in Figure $7 \mathrm{D}$, will provide consistent results, perhaps similar in magnitude to those from punched Northern gel analysis; however, many problems remain with quantitative studies at the autoradiographic level. Some of these difficulties are unique to in situ hybridization, while others are peculiar to autoradiographic quantitations in general. Of the former, we are particularly concerned about ribosomal loading: Whether, during periods of increased translational activity, efficient probe hybridization to mRNA is blocked by the increased ribosome loading known to occur (Palmiter, 1973), effectively underestimating the real mRNA increase. Similarly, questions of mRNA stability, hybridization efficiency (probe size), and the absence of adequate autoradiographic standards are paramount.

To summarize, we have reported the heterogeneity of response of AVP hypothalamic nuclei to osmotic stimuli. The total extent of this response occurs within the two magnocellular cell groups of the rat hypothalamus, the SON and PVN, and the extent of the increase in translatable AVP mRNA is proportional to that of total hybridizable AVP mRNA in both nuclei. Future directions for these studies involve the qualitative and quantitative assessment of osmotic response heterogeneity in the PVN by in situ hybridization.

\section{References}

Beynen, A. C. (1985) Biochemists and the diet of their rats. Trends Biochem. Sci. 10: 108-109.

Buijs, R. M. (1978) Intra- and extrahypothalamic vasopressin and oxytocin pathways in the rat. Cell Tiss. Res. 192: 423-435.

Burbach, J. P. H., M. J. De Hoop, H. Schmale, D. Richter, E. R. De Kloct, J. A. ten Haaf, and D. De Wied (1984) Differential responses to osmotic stress of vasopressin-neurophysin mRNA in hypothalamic nuclei. Neuroendocrinology 39: 582-584.

Chirgwin, J. M., A. E. Przybyla, R. J. MacDonald, and W. J. Rutter (1979) Isolation of biologically active ribonucleic acid from sources enriched in ribonuclease. Biochemistry 18: 5294-5299.

Claybaugh, J. R., and L. Share (1973) Vasopressin, renin, and cardiovascular responses to continuous slow hemorrhage. Am. J. Physiol. 224: 519-523.

Dierickx, K. (1980) Immunocytochemical localization of the vertebrate cyclic nonapeptide neurohypophysial hormones and neurophysins. Int. Rev. Cytol. 62: 119-185.

Dierickx, K., F. Vandesande, and J. DeMay (1976) Identification, in the external region of the rat median eminence, of separate neurophysin-vasopressin and neurophysin-oxytocin containing nerve fibers. Cell Tiss. Res. 168: 141-151.

Ferrario, C. M., H. Mikami, L. C. Michelini, Y. Kawano, and K. B. Brosnihan (1985) Interaction of vasopressin with central neurogenic mechanisms of blood pressure regulation. In Vasopressin, R. W. Schrier, ed., pp. 47-57, Raven, New York.

Gainer, H., Y. Sarne, and M. J. Brownstein (1977a) Neurophysin biosynthesis: Conversion of a putative precursor during axonal transport. Science 195: 1354-1356.

Gainer, H., Y. Sarne, and M. J. Brownstein (1977b) Biosynthesis and axonal transport of rat neurohypophysial proteins and peptides. J. Cell Biol. 73: 366-381.

Ivell, R., and D. Richter (1984) Structure and comparison of the oxytocin and vasopressin genes from rat. Proc. Natl. Acad. Sci. USA 81: 2006-2010.

Land, H., G. Schutz, H. Schmale, and D. Richter (1982) Nucleotide sequence of cloned cDNA encoding bovine arginine vasopressin-neurophysin II precursor. Nature 295: 299-303

Land, H., M. Grez, S. Rupport, H. Schmale, M. Rehnbein, D. Richter, and G. Schutz (1983) Deduced amino acid sequence from the bovine oxytocin-neurophysin I precursor cDNA. Nature 302: 342-344.

Lewis, M. E., T. G. Sherman, and S. J. Watson (1985) In situ hybridization histochemistry with synthetic oligonucleotides: Strategies and methods. Peptides 6 (Suppl. 2): 75-87.

Majzoub, J. A. (1985) Vasopressin biosynthesis. In Vasopressin, R. W. Schrier, ed., pp. 465-474, Raven, New York.

Majzoub, J. A., A. Rich, J. van Boom, and J. F. Habener (1983) Vasopressin and oxytocin mRNA regulation in the rat assessed by hybridization with synthetic oligonucleotides. J. Biol. Chem. 258: 14061-14064.

Makara, G. B., E. Stark, M. Karteszi, M. Palkovits, and G. Rappay (1981) Effects of paraventricular lesions on stimulated ACTH release and CRF in stalk-median eminence of the rat. Am. J. Physiol. 240: E441-E446.

Matsuguchi, H., F. M. Sharabi, F. J. Gordon, A. K. Johnson, and P. G. Schmid (1982) Blood pressure and heart rate responses to microinjection of vasopressin into the nucleus tractus solitarius. Neuropharmacology 21: 687-694.

McKinley, M. J., D. A. Denton, and R. S. Weisinger (1978) Sensors for antidiuresis and thirst: Osmoreceptors or CSF sodium detectors"? Brain Res. 141: 89-103.

Moses, A. M., and M. Miller (1971) Osmotic threshold for vasopressin release as determined by saline infusion and by dehydration. Neuroendocrinology 7:219-226.

Moses, A. M., and M. Miller (1974) Osmotic influences on the release of vasopressin. In Handbook of Physiology, Vol. 4, sec. 7, E. Knobil and W. H. Sawyer, eds., pp. 225-242, American Physiological Society, Washington, DC.

Negro-Vilar, A., and W. K. Samson (1982) On the role of arginine vasopressin in circumventricular organs. Ann. N.Y. Acad. Sci. 394: 753-758.

Palkovits, M., and M. J. Brownstein (1983) Microdissection of brain areas by the punch technique. In Brain Microdissection Techniques, A. C. Cuello, ed., pp. 1-36, Wiley, New York.

Palmiter, R. D. (1973) Ovalbumin messenger ribonucleic acid translation. J. Biol. Chem. 248: 2095-2106.

Pfeifer-Ohlsson, S., A. S. Goustin, J. Rydnert, T. Wahlstrom, L. Bjersing, D. Stehelin, and R. Ohlsson (1984) Spatial and temporal pattern of cellular myconcogene expression in developing human placenta: Implications for embryonic proliferation. Cell 38: 585-596.

Rasmussen, A. T. (1940) Effects of hypophysectomy and hypophysial stalk resection on the hypothalamic nuclei of animals and man. Assoc. Res. Nerv. Ment. Dis. 20: 245-269.

Rhodes, C. H., J. I. Morrell, and D. W. Pfaff (1981) Immunohistochemical analysis of magnocellular elements in rat hypothalamus: Distribution and number of cells containing neurophysin, oxytocin, and vasopressin. J. Comp. Neurol. 198: 45-64.

Sachs, H., and Y. Takabatake (1964) Evidence for a precursor in vasopressin biosynthesis. Endocrinology 7: 943-948.

Sachs, H., L. Share, J. Osinchak, and A. Carp (1967) Capacity of the neurohypophysis to release vasopressin. Endocrinology 81: 755-770.

Sawchenko, P. E., L. W. Swanson, and W. W. Vale (1984) Co-expression of corticotropin-releasing factor and vasopressin immunoreactivity in parvocellular neurosecretory neurons of the adrenalectomized rat. Proc. Natl. Acad. Sci. USA 81: 1883-1887.

Schmale, H., and D. Richter (1981) Immunological identification of a common precursor to arginine vasopressin and neurophysin II synthesized by in vitro translation of bovine hypothalamic mRNA. Proc. Natl. Acad. Sci. USA 78: 766-769. 
Schmale, H., S. Heinsohn, and D. Richter (1983) Structural organization of the rat gene for the arginine-vasopressin-neurophysin precursor. EMBO J. 2: 763-767.

Seif, S. M., A. B. Huellmantel, M. P. Platia, C. Haluszczak, and A. G. Robinson (1977) Isolation, radioimmunoassay and physiologic secretion of rat neurophysins. Endocrinology 100:1317-1326.

Sherman, T. G., and J. F. McKelvy (1982) Multiple forms of neurophysin precursor synthesized from Brattleboro rat hypothalamic RNA. Ann. N.Y. Acad. Sci. 394: 82-95.

Sherman, T. G., J. D. White, J. E. Krause, and J. F. McKelvy (1984) In vivo and in vitro study of neuropeptide biosynthesis. In Current Methods in Cellular Neurobiology, J. L. Barker and J. F. McKelvy, eds., pp. 103-145, Wiley, New York.

Sherman, T. G., H. Akil, and S. J. Watson (1985) Vasopressin mRNA expression: A Northern and in situ hybridization analysis. In Vasopressin, R. W. Schrier, ed., pp. 475-483, Raven, New York.

Swaab, D. F., C. W. Pool, and F. Nijveldt (1975) Immunofluorescence of vasopressin and oxytocin in the rat hypothalamo-neurohypophyseal system. J. Neural Transm. 36: 195-215.

Swanson, L. W., and H. G. J. M. Kuypers (1980) The paraventricular nucleus of the hypothalamus: Cytoarchitectonic subdivisions and the organization of projections to the pituitary, dorsal vagal complex and spinal cord as demonstrated by retrograde fluorescence double-labeling methods. J. Comp. Neurol. 194: 555-570.

Swanson, L. W., and P. E. Sawchenko (1983) Hypothalamic integra- tion: Organization of the paraventricular and supraoptic nuclei. Ann. Rev. Neurosci. 6: 269-324.

Travis, R. H., and L. Share (1971) Vasopressin-renin-cortisol interrelations. Endocrinology 89: 246-253.

Valiquette, G. (1980) Posterior pituitary hormones and neurophysins. In The Endocrine Functions of the Brain, M. Motta, ed., pp. 385417, Raven, New York.

Vernay, E. B. (1947) The antidiuretic hormone and the factors which determine its release. Proc. R. Soc. London [Biol.] 135: 25-106.

Watson, S. J., N. G. Seidah, and M. Chretien (1982) The carboxy terminus of the precursor to vasopressin and neurophysin: Immunocytochemistry in rat brain. Science 217: 853-855.

Watson, S. J., H. Khachaturian, N. G. Seidah, M. Chretien, E. Zimmerman, G. Nilaver, and T. B. van Wimersma Gredianus (1983) Immunocytochemistry of the C-terminal peptide of propressophysin (CPP): Relationship to vasopressin, oxytocin and neurophysin. Neuropeptides 3: 321-336.

Wolfson, B., R. W. Manning, L. G. Davis, R. Arentzen, and F. Baldino, Jr. (1985) Co-localization of corticotropin releasing factor and vasopressin mRNA in neurons after adrenalectomy. Nature 315: 5961.

Zerbe, R. L., and M. Palkovits (1984) Changes in the vasopressin content of discrete brain regions in response to stimuli for vasopressin secretion. Neuroendocrinology 38: 285-289. 